\title{
A mussel tissue certified reference material for multiple phycotoxins. Part 1: design and preparation
}

\author{
Pearse McCarron 1, 2, *, Håkan Emteborg ${ }^{3}$, Cíara Nulty², Thomas Rundberget ${ }^{4}$, Jared I. Loader ${ }^{5,6}$, \\ Katharina Teipel ${ }^{2}$, Christopher O. Miles ${ }^{4,5}$, Michael A. Quilliam ${ }^{1}$, Philipp Hess ${ }^{2,7}$
}

\author{
${ }^{1}$ National Research Council Canada, Institute for Marine Biosciences, 1411 Oxford St, Halifax, Nova Scotia, B3H \\ 3Z1, Canada \\ ${ }^{2}$ Marine Institute, Rinville, Oranmore, Galway, Ireland \\ ${ }^{3}$ European Commission, Joint Research Centre, Institute for Reference Materials and Measurements, \\ Retieseweg 111, 2440 Geel, Belgium \\ ${ }^{4}$ National Veterinary Institute, P.O. Box 750 Sentrum, NO-0106 Oslo, Norway \\ ${ }^{5}$ AgResearch Ltd., Private Bag 3123, Hamilton 3240, New Zealand \\ ${ }^{6}$ Present address: Hill Laboratories Ltd, Private Bag 3205, Hamilton 3240, New Zealand \\ ${ }^{7}$ Present address: Ifremer, Rue de l'île d'Yeu, Nantes, CEDEX 03, France \\ *: Corresponding author : Pearse McCarron, tel. : 902403 3049, fax. : 9024265426 \\ email address : pearse.mccarron@nrc-cnrc.gc.ca
}

\begin{abstract}
:
The development of multi-analyte methods for lipophilic shellfish toxins based on liquid chromatography-mass spectrometry permits rapid screening and analysis of samples for a wide variety of toxins in a single run. To ensure accuracy of results, validated methods and appropriate certified reference materials (CRMs) are required. CRMs are essential for accurate instrument calibration, for assessing the complete analytical method from sample extraction to data analysis, and for verifying trueness. However, CRMs have hitherto only been available for single toxin groups.

Production of a CRM containing six major toxin groups was achieved through an international collaboration. Preparation of this material, CRM-FDMT1, drew on information from earlier studies as well as improved methods for handling bulk tissues, production of reference materials, and isolation of toxins. Previous investigations of stabilisation techniques indicated freeze-drying to be a suitable procedure for preparation of shellfish toxin RMs and applicable to a wide range of toxins. CRM-FDMT1 was initially prepared as a bulk wet tissue homogenate with planned concentrations of domoic acid, okadaic acid, dinophysistoxins, azaspiracids, pectenotoxins, yessotoxin and spirolides. The homogenate was then freeze dried, milled and bottled in aliquots suitable for distribution and analysis. The moisture content and particle size distribution were measured, and determined to be appropriate. A preliminary toxin analysis of the final material showed a comprehensive toxin profile.
\end{abstract}

Keywords : CRM-FDMT1 ; certified reference material ; shellfish toxins ; phycotoxins ; accuracy ; precision ; liquid chromatography - mass spectrometry. 


\section{Introduction}

Shellfish are valued as a nutritionally healthy food and are consumed in almost every part of the world. Increased demand in recent years has resulted in significant growth of the shellfish industry worldwide. If toxigenic algae bloom in a shellfish growing area, shellfish may become toxic. While few effects on the shellfish are usually observed, human consumption of shellfish contaminated with phycotoxins has led to numerous poisoning incidents [1-3]. This can also have major effects on the economy of the aquaculture industry. Comprehensive toxin monitoring programs are in place to protect human health and the toxin levels in shellfish tissues are regulated in most jurisdictions. For many years the mouse bioassay (MBA) [4] was the existing reference method for lipophilic shellfish toxins and it has been reasonably effective as a non-specific indicator of toxicity. However, there are numerous problems with testing on animals: ethical issues; lack of sensitivity resulting in false negatives; lack of specificity which can lead to false positives; inability to distinguish between different toxins groups; unsuitable for multi-toxin detection; and lack of internationally accepted validation. The need for alternative and validated methods is therefore widely accepted [5]. Consequently, much research has gone into development of chemical analytical methods for monitoring [6-10]. As there are various toxin groups regulated, it is desirable to have multi-toxin methods. As a result, procedures based on liquid-chromatography coupled with mass-spectrometry (LC-MS) are rapidly becoming the methods of choice [11-14].

Alternative methods to the MBA can only be implemented once they are validated and accurately calibrated. Reference materials (RMs) are necessary for such operations and to fulfil the quality control requirements of official testing laboratories. [15-18]. Unfortunately the limited availability of shellfish toxin RMs has restricted progress in development and validation of alternative methods.

Some work has been done the production of RMs for shellfish toxins [19-21], however, these materials were not certified or widely available. Since the domoic acid (DA) poisoning event [22] the National Research Council's CRM Program (CRMP) has produced a number of phycotoxin CRMs [23]. Calibrant CRMs are currently available for DA, okadaic acid and dinophysistoxins (OA \& DTXs), azaspiracids (AZAs), yessotoxin (YTX), pectenotoxins (PTX2), spirolides (13-desMe-C SPX) and a range of paralytic shellfish poisoning (PSP) toxins [24]. Along with calibrants it is necessary to have matrix CRMs that comprise the analyte(s) of interest present in their natural form, and in their natural environment. These test and validate each step of an analytical method. CRMP distributes mussel (Mytilus edulis) matrix CRMs for DA and OA/DTX groups. However, a multi-toxin matrix CRM is a necessity for development and validation of multi-toxin methods.

A collaborative project was commenced with the aim of producing and certifying a candidate matrix CRM for multiple groups of lipophilic shellfish toxins. Collaborators provided contaminated tissues, algal pastes, purified/semi-purified toxins, or contributed expertise in the preparation and characterisation work. The major toxin groups and analogs represented in the candidate CRM are shown in Fig. 1.

In order for RMs/CRMs to be fit for purpose they must satisfy the requirements of homogeneity and stability. Additionally they must be representative of samples analysed on a day-to-day basis in testing laboratories. Mussel (Mytilus edulis) was chosen as the matrix for the candidate CRM as this is a commonly distributed shellfish species and mussels 
frequently accumulate phycotoxins to high levels. From the point of view of homogeneity and stability it must be ensured that all steps involved in the handling and processing of the material, up until final bottling and storage, facilitate these requirements [18]. Stabilisation of a multi-toxin material presented a significant challenge due to the variety of groups of toxins present, each with different stabilities and susceptibilities under varying conditions. Heat treatment has been investigated for DA and OA group toxins $[25,26]$ and thermal sterilisation was used for stabilization of matrix CRMs containing these toxins $[27,28]$. However, this method is inappropriate for the AZAs [29]. A feasibility study on gamma-irradiation showed that it was suitable for various toxin groups [30]. However, long-term stability information is not available for this treatment for many of the toxin of interest in this project. The simple use of stabilisers has proven to be an efficient way of maintaining the stability of mussel tissue RMs or DA [31]. However, limited data is available on the effectiveness of additives for stabilization of lipophilics toxins. Drying is a common stabilisation method for biological matrix RMs [32], with freeze-drying particularly suitable for heat sensitive compounds thanks to the gentle manner of the process. A feasibility study showed that freeze-drying was very effective for a variety of toxins [33]. No degradation of DA was observed over a 9-month period at temperatures up to $40^{\circ} \mathrm{C}$, while degradation was observed in an equivalent wet homogeneate after only a number of days. Improved stability was also observed for lipophilic analytes. Taking all the available information into account and considering the value of the toxin materials used, it was decided that in order to ensure optimum stability of the multi-toxin material would be prepared as a freeze-dried mussel powder.

This paper outlines extensive work done in characterisation of the raw materials, design and preparation of a bulk wet homogenate, freeze-drying the wet material, production of an homogenous powder, and finally bottling of the candidate CRM. Toxin concentrations of the constituent wet tissues are shown, the physical characterisation of the freeze-dried powder is described, and an indicative concentration profile of the candidate CRM is given.

\section{Experimental}

\section{1. standards and Chemicals}

Methanol, ethanol and acetonitrile were obtained as pesticide grade solvents (Pestican®) (Labscan, Dublin, Ireland). A reverse osmosis purification system supplied water for the mobile phase (Barnstead International, Dubuque, IA, USA). Formic acid, ammonium formate, trifluoroacetic acid, ethoxyquin, oxytetracycline, ampicillin and erythromycin were obtained from Sigma-Aldrich (St. Louis, MO, USA).

DA, OA, PTX2 and 13-desMe-SPX-C calibration standards were prepared from certified calibration solutions (NRC-IMB, CRMP, Halifax, NS, Canada: CRM-DA-d, CRM-OA, CRMPTX2, CRM-SPX1). The OA standard was used for quantitation of DTX1 and DTX2 assuming equi-molar response factors. AZA1 isolated under supervision of Dr. M. Satake [Hess P (2001) Marine Institute, unpublished internal report] was used for calibration of AZA1, AZA2 and AZA3, assuming equi-molar response factors. 


\subsection{Collation and Processing of mussel (Mytilus edulis) tissues (marine Institute)}

\subsubsection{Material A (Canadian mussel whole flesh containing DA)}

Mussels containing high levels of DA were obtained in Cardigan Bay, Eastern Prince Edward Island (Canada, December 1987). After harvesting they were steam cooked for 10 min, shucked and placed in long-term freezer storage $\left(-20^{\circ} \mathrm{C}\right)$. For the CRM production $5 \mathrm{~kg}$ of these mussels were shipped to the Marine Institute.

Significant desiccation of the material had occurred during storage so $2 \mathrm{~kg}$ of water was added to $4 \mathrm{~kg}$ of the whole flesh and this was mixed using a Waring blender (Hartford, CT, USA). To further homogenize a Polytron (PT6100, Kinematica, Lucerne, Switzerland) was used. To inactivate enzymes the homogenate was autoclaved at $121^{\circ} \mathrm{C}$ for 15 min (Touchclave LAB K200E, Davidson \& Hardy Ltd., Dublin, Ireland). After autoclaving the material was re-homogenized using the Polytron with coarse grade followed by fine grade dispersing aggregates. Byssus and shell debris were removed at this stage.

\subsubsection{Material B (Norwegian mussel hepatopancreas containing DTX1)}

Mussels harvested in Floedevigen, Norway in 2006 were steam cooked 10 min and then shucked. Post processing monitoring found that the tissues contained significant levels of DSP toxins, primarily DTX1. A quantity of the processed material was shipped to the Marine Institute.

Approximately $11 \mathrm{~kg}$ of hepatopancreas tissues were dissected using scalpels and then autoclaved (conditions as above). After autoclaving, de-ionised water $(750 \mathrm{~mL})$ was added to $10.75 \mathrm{~kg}$ of the tissue. This was homogenized in $2 \mathrm{~kg}$ lots using a Waring blender and then the Polytron. All the hepatopancreas material was then combined in a $27 \mathrm{~L}$ bucket and blended using a Silverson DX batch homogeniser (Silverson Ltd., Bucks, UK).

\subsubsection{Material C (Castletownbere remainder tissues containing OA, DTX2 and AZAs)}

Mussels contaminated with OA, DTX2 and AZAs were retrieved from Castletownbere (Bantry Bay, Southwest Ireland, 2001). The hepatopancreas of these mussels had been removed for use in toxin isolation work [34] leaving bulk quantities of remainder tissues in storage $\left(-20^{\circ} \mathrm{C}\right)$. As a significant quantity of hepatopancreas tissues were being used from the Norwegian tissues (Material B) it was desirable to use some remainder tissues to maintain a 'typical' whole flesh balance for the candidate CRM.

The tissue was autoclaved to eliminate enzymatic activity. Although it had been homogenized after dissection of the hepatopancreas it was necessary to re-homogenise to ensure representative sub-sampling of the bulk for toxin characterisation. Approximately $35 \mathrm{~kg}$ of the remainder material was blended and homogenized using the Waring blender, followed by the Polytron, and finally with the Silverson mixer. Prior to the Polytron step $6 \mathrm{~kg}$ of de-ionized water was added to the bulk to improve fluidity. 


\subsubsection{Material D (Bruckless mussel whole flesh containing AZAs)}

Mussels with high levels of AZAs were collected from the Northwest Irish coast (McSwyne's Bay, Bruckless, Co. Donegal, September 2005). After harvesting the mussels were steam cooked for $12.5 \mathrm{~min}$, removed from the shell, and vacuum packed in $1 \mathrm{~kg}$ bags for storage $\left(-20^{\circ} \mathrm{C}\right)$.

After removal of byssus and shell debris $18.5 \mathrm{~kg}$ of the whole flesh was autoclaved. Autoclaving also serves to stabilise the AZA toxin profile in naturally contaminated tissues [35]. The material was processed with a Waring blender ( $3 \mathrm{~kg}$ portions), adding $5.5 \mathrm{~kg}$ of de-ionized water in total to achieve the required consistency. The portions were further homogenized using a Polytron, before combining for final mixing with the Silverson homogeniser.

\subsubsection{Material E (Ardgroom whole flesh containing OA and DTX2)}

Mussels contaminated with OA and DTX2 were harvested from the Southwest of Ireland (Ardgroom, Kenmare Bay, Co. Kerry, 2004). The shellfish were steam cooked for 10 min after harvesting, shucked, and vacuum packed in $1 \mathrm{~kg}$ portions for storage $\left(-20^{\circ} \mathrm{C}\right)$.

The mussels were processed in the same way as material D (cleaning, autoclaving, addition of water, blending, homogenizing). In total, $55 \mathrm{~kg}$ of homogenate was prepared from the Ardgroom mussels.

\subsection{Non mussel tissue materials}

\subsubsection{Purified yessotoxin}

A sample (58 $\mathrm{mg}$ ) of purified yessotoxin prepared as the disodium salt from an algal culture [36] was stored in $\mathrm{MeOH}$ in 6 vials at $-20^{\circ} \mathrm{C}$. The material was evaporated to dryness under nitrogen for shipping, and then transferred with $\mathrm{MeOH}(6 \times 0.5 \mathrm{~mL}$ rinses per vial) to a $50 \mathrm{~mL}$ volumetric flask that was made up to volume with $\mathrm{MeOH}$.

\subsubsection{Alexandrium ostenfeldii pellet}

Eight centrifuge tubes containing Alexandrium ostenfeldii biomass from a culture established from isolates from Ship Harbour, Nova Scotia, Canada were stored frozen. This culture contained a number of SPXs [37], most significantly 13-desMe-C SPX. After defrosting, $10 \mathrm{~mL}$ of $\mathrm{MeOH}$ was added to each tube and then vortex mixed for a few seconds. The content of the tubes were then transferred to a flask. This process was repeated 3 times for each tube to retrieve the entire pellet. The flask containing the combined biomass was made up to $500 \mathrm{~g}$ with $\mathrm{MeOH}$. 


\subsubsection{Dinophysis spp. extract containing PTX2}

An ethereal extract produced during purification of material collected from natural populations of Dinophysis spp. in Spain and Norway [38] was evaporated to dryness under nitrogen to form a paste (approximately $40 \mathrm{~g}$ ) containing PTX2 (approximately $15 \mathrm{mg}$ ). The material was shipped in four tubes, the contents of which were transferred to a pre-weighed $250 \mathrm{~mL}$ volumetric flask (with $\mathrm{MeOH} 3 \times 10 \mathrm{~mL}$ per tube) and the flask was made up to volume with $\mathrm{MeOH}$.

\subsection{Toxin determination}

\subsubsection{DA extraction and analysis}

Samples $(4 \mathrm{~g})$ of the processed materials were extracted twice using $16 \mathrm{~mL}$ volumes of $50 \%$ aqueous $\mathrm{MeOH}$ and made up to $50 \mathrm{~mL}$. Aliquots of the combined phases made up to volume were filtered through $0.2 \mu \mathrm{m}$ filters (Schleicher \& Schuell, Whatman, Brentford, UK) into HPLC vials for analysis. DA was determined as the sum of DA and epi-DA, closely following the procedure published by Quilliam et al. [39] with some minor modifications [40]. A Shimadzu HPLC system with a photodiode array (PDA) detector was used (Shimadzu Inc., Kyoto, Japan). A Vydac column $(250 \mathrm{~mm} \times 4.6 \mathrm{~mm})$ packed with $5 \mu \mathrm{m} 201 \mathrm{TP}_{18}$ silica, was eluted isocratically with $9 \%$ acetonitrile in water with $0.1 \%$ trifluoroacetic acid. The column flush was flushed with $90 \%$ acetonitrile at the end of each run.

\subsubsection{Lipophilic toxin extraction and analysis (OA and AZA groups)}

Aliquots $(2 \mathrm{~g})$ of the processed materials were extracted twice with $9 \mathrm{~mL}$ volumes of $100 \%$ $\mathrm{MeOH}$. Extracts were combined in $25 \mathrm{~mL}$ volumetric flasks and made up to the mark with extraction solvent [30]. OA group esters were determined using the base hydrolysis method [41]. Extracts were passed through $0.2 \mu \mathrm{m}$ filters into HPLC vials for analysis.

Analysis was performed by LC-MS/MS using a 2695 Waters HPLC coupled to a triple stage quadrupole (Quattro Ultima, Micromass, Dublin, Ireland) equipped with a z-spray ESI source. A multi-toxin method was adapted from Quilliam et al. [11]. A binary mobile phase was used, with $A$ (100\% aqueous) and B (95\% acetonitrile) each containing $2 \mathrm{mM}$ ammonium formate and $50 \mathrm{mM}$ formic acid. A gradient was run at $250 \mu \mathrm{L} / \mathrm{min}$ on a $50 \mathrm{~mm} \times 2 \mathrm{~mm}$ i.d., $3 \mu \mathrm{m}$ BDS-Hypersil C8 column (Thermo Fisher Scientific, Loughborough, U.K.) with a $10 \mathrm{~mm} \times 2$ $\mathrm{mm}$ guard column. Starting with $30 \% \mathrm{~B}$ at time zero, B was raised to $90 \%$ at $8 \mathrm{~min}$. Then, the $90 \%$ B was held for $2.5 \mathrm{~min}$, decreased to $30 \%$ B over $0.5 \mathrm{~min}$ and was held again for $3 \mathrm{~min}$ until the next run. Analyses were conducted using MRM mode (OA/DTX2 $[M-H]: m / z$ 803.5 $>255.1$; DTX1 [M-H]: $\mathrm{m} / \mathrm{z}$ 817.5>255.1. AZA1, $-2,-3[\mathrm{M}+\mathrm{H}]^{+}: \mathrm{m} / \mathrm{z}$ 842.5>672.5, $856.5>672.5,828.5>658.5$, respectively. With this method OA and the DTXs eluted first (ca. 6.5 - $8 \mathrm{~min}$ ), followed by the AZAs (ca. 10-12 min). 


\subsubsection{Analysis of non-tissue materials}

For analysis of PTX2 in the Dinophysis spp. extract, a dilution in $\mathrm{MeOH}$ was prepared and the LC-MS method used for OA and AZA was applied using $[M+H]^{+} \mathrm{m} / \mathrm{z} \quad 876.5>823.5$ as the quantitative PTX2 transition.

A sample of the Alexandrium ostenfeldii pellet was extracted by sonicating in $\mathrm{MeOH}$. 13-desMe-C SPX was analysed on an Acquity UPLC (Waters Inc., Dublin, Ireland) coupled to a Micromass Q-ToF Ultima (quadrupole-time-of flight hybrid) (Dublin, Ireland). The binary mobile phase described for the lipophilic toxins was used with an Acquity UPLC BEH C18 column $(2.1 \times 100 \mathrm{~mm}$ i.d., $1.7 \mu \mathrm{m})$ running a gradient at $400 \mu \mathrm{L} / \mathrm{min}$ from $30 \%$ to $90 \% \mathrm{~B}$ over $3 \mathrm{~min}$, and then holding for $1.5 \mathrm{~min}$ before re-equilibrating. The Q-ToF was operated in ToF-MS-MS mode doing quantitation on $\mathrm{m} / \mathrm{z} 692.5\left([\mathrm{M}+\mathrm{H}]^{+}\right)$.

The purified YTX material had been quantified at AgResearch prior to receipt at the Marine Institute.

\subsubsection{Moisture content analysis}

Aliquots of tissue $(1-2 \mathrm{~g})$ were weighed into the pre-weighed centrifuge tubes. The tubes were then placed in a Jouan RC10.22 rotary drier (Jouan, Saint Herblain, France), dried under vacuum (optimized conditions: 950 min run, \#4 heat setting, Pulse vent "OFF"), and the mass retaken after cooling to determine moisture content by loss.

\subsection{Combination of materials and Bulk homogenization (marine Institute)}

Following characterisation of the individual tissue materials, the quantities required for an appropriate toxin profile in the candidate CRM were decided upon. Due to the scale of the preparation $(>100 \mathrm{~kg})$, a homogenization procedure was designed so that it would begin with the smallest quantities of tissues in small vessels, and move to increasingly larger vessels as the bulk increased, until finally all the separate materials and required water were combined.

\subsubsection{Procedure}

Material $\mathrm{A}(5.5 \mathrm{~kg})$ was mixed in a $10 \mathrm{~L}$ bucket with a solution containing a combination of additives (30 $\mathrm{g}$ each of ethoxyquin, ampicillin, oxytetracycline and erythromycin in $800 \mathrm{~g}$ of ethanol). The YTX, PTX2 and Alexandrium ostenfeldii solutions were added at this stage, and each container was rinsed with $100 \mathrm{~mL}$ of ethanol, followed by $100 \mathrm{~mL}$ of water, to ensure complete transfer. The contents of the bucket were homogenized thoroughly using the Polytron (fine dispersing aggregate at 5000 rpm for $13 \mathrm{~min}$; coarse dispersing aggregate at $3500 \mathrm{rpm}$ for $10 \mathrm{~min})$.

This combined material was transferred to a $27 \mathrm{~L}$ bucket, rinsing with $500 \mathrm{~g}$ of water. Material B was added $(11.2 \mathrm{~kg})$ and homogenized using the Silverson mixer for $15 \mathrm{~min}$. This homogenate was then transferred to a $210 \mathrm{~L}$ drum rinsing the $27 \mathrm{~L}$ bucket carefully with $1 \mathrm{~L}$ of water. Approximately $20 \mathrm{~kg}$ of material $\mathrm{D}$ was added and the contents of the drum were homogenized using the Silverson mixer for $30 \mathrm{~min}$. 
Next $29 \mathrm{~kg}$ of the material $\mathrm{C}$ was added, along with $10 \mathrm{~kg}$ of water for adjusting the moisture content of the final bulk homogenate. The combined materials were homogenized for $35 \mathrm{~min}$ using the Silverson blender.

Lastly $52 \mathrm{~kg}$ of material $\mathrm{E}$ was added. The Silverson mixer was in operation at a slow speed while these tissues were being added. The contents of the drum were then mixed for 35 min using the Silverson blender. At this stage the remaining quantity of water $(16.5 \mathrm{~kg})$ required to adjust the water content of the final bulk was added. The combined bulk homogenate $(150 \mathrm{~kg})$ was mixed for a further $60 \mathrm{~min}$ using the Silverson blender, stopping intermittently to remove any byssus threads that had collected on the mixing head.

\subsubsection{Packaging and shipment to IRMM}

The bulk homogenate was divided as $2.5 \mathrm{~kg}$ portions into $3 \mathrm{~L}$ containers. Throughout this process the remaining tissues in the drum were intermittently mixed until all the material had been sub-divided. The individual $2.5 \mathrm{~kg}$ portions were carefully sealed, frozen at $-20^{\circ} \mathrm{C}$, and then shipped to the Insitute for Reference Materials and Measurements (IRMM) in polystyrene boxes on a pallet using an overnight courier.

\subsection{Freeze-drying, processing and bottling of wet homogenate (IRMM).}

\subsubsection{Freeze-drying}

Thawing of the wet homogenate had just commenced when the raw material arrived at IRMM. The material was split into four batches for freeze-drying. The contents were poured into a plastic drum, rinsing each with approximately $100 \mathrm{~mL}$ of de-ionised water to recover all material. The slurry was manually homogenized using a Teflon paddle and subsequently transferred to flat-bottomed freeze-drying trays $(30 \times 45 \mathrm{~cm})$, which were then placed in a pre-cooled freeze-drier Epsilon 2-85D (Martin-Christ, Osterode, Germany). Three Pt100 sensors and one lyo-control sensor were placed in the homogenate in trays positioned in the top, in the middle, and in the bottom of the drying chamber. An established 4 day freeze-drying program [33] was started with the following sequence of events: freezing, sublimation, and secondary drying. The water content of each batch was checked by Karl Fisher titration (KFT) (Metrohm, Herisau, Switzerland) after freeze-drying cycle to determine completion of the process (Supporting Information, Table 1.). Values varied between 2.8 and $4.7 \%$ and were acceptable as the samples were taken prior to powder homogenization.

\subsubsection{Crushing, milling sieving and homogenization}

Dried batches were kept in sealed stainless steel drums at $-20^{\circ} \mathrm{C}$ until completion of the four freeze-drying cycles. The dried material was pre-crushed in the drums to a fine powder using a heavy Teflon pestle. The drums were then placed in liquid nitrogen for pre-freezing and the powder was cryogenically milled using a PALLA VM-KT vibrating mill (KHD HumboldtWedag, Köln, Germany) in the temperature range $-100{ }^{\circ} \mathrm{C}$ to $-196{ }^{\circ} \mathrm{C}$. Immediately after milling the particle size distributions of the batches were determined by laser diffraction using 
Sympatec Helos equipment (Clausthal-Zellerfeld, Germany) (method accredited at IRMM under ISO 17025).

Each batch was sieved (Russel Finex Industrial Sieve, London, UK) through a $250 \mu \mathrm{m}$ stainless steel mesh, with steel-rings placed on the mesh to break agglomerates. Yields $>95 \%$ were achieved with only non-tissue particles of sand and silt remaining on the sieve.

Batches were pooled and homogenized in a screw-capped drum using a T-200 Turbula mixer (WAB, Turbula, Basel, Switzerland) for $30 \mathrm{~min}$. The material was divided in 20 portions and thermally sealed in polyethylene bags for ease of handling during bottling.

\subsubsection{Bottle filling, capping and labelling}

A filling machine (All-Fill International Ltd., Sandy, Bedfordshire, UK) was set up to dispense the powder into $30 \mathrm{~mL}$ amber glass vials. The glove-box surrounding the filling machine was purged with nitrogen. Lyophilisation inserts were automatically pressed down into the necks of the vials after filling to preserve an inert atmosphere inside the containers.

Bottles were capping and labelled in fill order using assemblies from Bausch \& Ströbel (Ilshofen, Germany) and BBK (Beerfelden, Germany), respectively. The capping machine was operated at 10 vials per minute with manual loading and unloading of vials.

\subsubsection{Analytical production control by water content and particle size analysis}

A Luminar 4030 Acousto-Optical Tunable Filter Near Infrared Spectrometer (AOTF-NIR, Brimrose, MD, USA) was installed on the capping machine. This recorded 100 NIR spectra for each bottle, and the data was then evaluated and calibrated with a partial least squares model [42]. As a final production control, 12 bottles of the product were selected over the entire fill series to measure water content by KFT.

On the same 12 units selected for KFT, the particle size distribution was analysed using the Sympatec Helos laser diffraction instrument. The powder was loaded in a $50 \mathrm{~mL}$ cuvette with isopropanol and a diffraction measurement was performed for $10 \mathrm{sec}$. Each unit was measured twice (i.e. two separate loadings per bottle).

Finally, micrographs of the material were obtained using a $100 \mu \mathrm{m}$ scale (certified length).

\subsubsection{Storage at IRMM and preliminary toxin analysis}

The stock material was retained at the IRMM $\left(-20^{\circ} \mathrm{C}\right)$ until appropriate conditions of transport and storage were verified from stability studies. Some bottles of CRM-FDMT1 were also shipped chilled to the Marine Institute for a preliminary toxin analysis of the material. Extraction and instrumental methods described for stock tissues materials were used. The freeze-dried powder was reconstituted for extraction following the method reported previously [33] 


\section{Results and discussions}

\subsection{Characterisation of consituent materials}

While it would not be practical to have every known toxin present in the material, a minimum requirement was that the material would contain a representative analog from each of the EU regulated classes of lipophilic compounds (OA/DTXs, AZAs, PTXs, YTXs) [43]. The various mussel tissues used were identified through regulatory and post-processing monitoring programs to be suitable for combination in a candidate CRM as they would contribute to a comprehensive and appropriate toxin profile. Water content and toxin concentrations for each of the individually processed tissue materials are given in Table 1 . The majority of the mussel materials required for the OA and AZA groups were obtained from toxin events that occurred in Ireland. However, DTX1 is typically only found at trace levels in Irish shellfish [44] so mussels harvested in Norway were obtained containing levels of DTX1 close to the regulatory limit. Hepatopancreas tissues were dissected in order to increase the concentration added, although this still required a considerable quantity of material. It was decided to also incorporate DA in the CRM as this hydrophilic toxin is often included in multi-toxin monitoring procedures for screening purposes $[13,14]$. The mussels harvested in Prince Edward Island were implicated in the initial amnesic shellfish poisoning episode [22] and contained DA at a concentration almost 30 times the EU regulatory limit. As all the tissues had been cooked or thermally treated during processing, the water contents were lower than what would typically be expected for fresh tissues.

A number of toxins were obtained from non-shellfish tissue sources. The Dinophysis spp. extract contained approximately $15 \mathrm{mg}$ of PTX2. Because this extract was only partially purified there were significant concentrations of OA and DTX1 also present (approximately 2.6 and $10.9 \mathrm{mg}$ respectively). SPXs were included in the candidate CRM as a nonregulated lipophilic toxin class. Analysis of the Alexandrium ostenfeldii biomass gave an indicative total quantity of approximately $50 \mathrm{mg}$ of 13-desMe-SPX-C. Based on quantitation at AgResearch there was a total of $58 \mathrm{mg}$ of YTX in the dried YTX residues.

\subsection{Combination of tissues and preparation of bulk wet homogenate (marine Institute)}

The most important consideration in the design process was to have a toxin profile and toxin concentrations that would be relevant for end users of the material, i.e. regulated toxins represented at concentrations near the regulatory limits. A further aim was to be able to certify as many of the analytes in the candidate CRM as possible, while avoiding excessive uncertainties for the certified values. Therefore, it was desirable not to have too many analytes present at impedingly low levels. However, these types of natural products are extremely rare and valuable, so a limiting factor in some instances was the low concentrations present in the contaminated mussel materials available.

Based on the information obtained for the different materials (Table 1) a combination of tissues and toxin materials was prepared using the quantities outlined in Table 2. Due to the high level of DA present in material $A$, a relatively small proportion of this tissue was needed to have a concentration in the final bulk wet homogenate approximately at the EU regulatory 
level. All the dissected Norwegian hepatopancreas (material B) was included in the mix to provide a base level concentration for DTX1, although this contribution was still relatively low. In order to maintain an overall whole flesh profile in the CRM, remainder tissues from Castletownbere (material $\mathrm{C}$ ) were used to counter balance the large amount of Norwegian hepatopancreas. Material C contained OA, DTX2 and AZAs at levels sufficient to maintain a desirable profile for these toxins, while the quantity of tissue added did not significantly dilute concentrations of the other analytes in the material. The major contributor for AZAs was the Bruckless tissues (material D), which also contained OA. The Ardgroom tissue (material E) was added in the most significant quantity. This was primarily contaminated with OA and DTX2, and a benefit of this tissue was that it also contained high levels of OA and DTX2 esters, adding to the diversity of the toxin profile in the material. In the initial homogenisation stages the non-tissue materials were added, along with stabilising additives. The additives were included to prolong stability of the wet homogenate in the event of delays when shipping the bulk to the IRMM for freeze-drying. Although this was based on the findings of previous work [31], no information is available on their stabilizing properties for phycotoxins RMs in combination with freeze-drying. In addition to providing a PTX2 spike for the CRM, the Dinophysis spp. extract also contained significant levels of OA and DTX1. This was particularly beneficial for DTX1 as material B only provided a low concentration of this analyte.

A final consideration was adjustment of moisture content. Although the homogenate was to undergo freeze-drying to produce a powder RM, previous feasibility studies indicated that for efficient freeze-drying of this matrix it is desirable to have sufficiently adjusted moisture content in the initial wet material [H. Emteborg, IRMM, pers comm]. Based on moisture content determinations of the individual tissues (Table 1) a combination of the quantities outlined would result in a combined material with a water content of $80.8 \%$. This was adjusted to approx. 85\% during the homogenisation. The process leading to the production of the bulk homogenate is schematically represented in Fig. 2. Based on concentrations determined for the individual tissue materials (Table 1) and the amounts of the various materials used (Table 2), indicative concentrations of the major toxins present in the bulk wet homogenate are shown at the bottom of Table 2 (as $\mathrm{mg} / \mathrm{kg}$ of wet tissue).

\subsection{Freeze-drying and physical characterisation of material (IRMM)}

The production and characterisation process of the freeze-dried powder is schematically summarized in Fig 3. A total of 6918 units were filled with slightly more than $3 \mathrm{~g}$ in each. The bottle label included the material name (NRC CRM-FDMT1), a brief description of the material (Multi-toxin Mussel Tissue CRM), lot and sample numbers, a short safety precaution (not suitable for human consumption), and institute logos of the project collaborators. Once the bottles were capped and labelled they were placed in storage at $-20^{\circ} \mathrm{C}$. As part of the post-production process, a series of physical characterisation studies were carried out. An important parameter for freeze-dried materials is water content. In freeze-drying the main aim is to have a sufficiently low water content to inhibit microbiological activity, but it is also necessary to avoid decreasing the moisture level too much as this would lead to the material becoming hygroscopic. The moisture contents of each bottle were determined by AOTF-NIR during bottling $(\mathrm{m} / \mathrm{m} 2.9 \%, \pm 0.3, \mathrm{n}=6918)$ showing no trends. This indicated highly reproducible filling conditions (Supporting Information, Fig. 1). For a higher degree of accuracy and precision, 12 bottles of CRM-FDMT1 were selected over the entire fill series and moisture contents were determined using a fully validated KFT method $(\mathrm{m} / \mathrm{m} 3.9 \%, \pm$ $0.6, n=12$, expanded uncertainty $k=2$ ). Although there is a slight systematic difference 
between the KFT and the AOFT-NIR values, the results are in reasonable agreement. Water content in the range of 3 to $4 \%$, as achieved here, is rather optimal for dry biological powders with respect to matrix stability, as at this level there should be a low risk of bacterial growth or chemical reactions [45].

Particle size information is important when considering the minimum sample intake of a powder, as this influences the uncertainty of the result obtained. Additionally, particle size analysis is a good indication of the effectiveness of the processing procedure, particularly the milling and sieving steps. Analysis of CRM-FDMT1 showed that the average particle size was approximately $50 \mu \mathrm{m}$ (Fig. 4), and was similar to that obtained in the previous feasibility study [33]. The cumulative distribution shows that $90 \%$ of particles are smaller than $120 \mu \mathrm{m}$ (Table 3) corresponding to the very high yield from the sieving through the $250-\mu \mathrm{m}$ mesh. The relative standard deviations between the different units is around $5 \%$ for the size classes from $\mathrm{X}_{16}$ and upwards, confirming particle size uniformity over the whole production batch.

Micrographs are a valuable complement to particle size distribution measurements as they can reveal colour differences, fractionations due to particle shape, and they provide a visual indication of particle size based on direct comparison with a certified length scale. From the micrographs of CRM-FDMT1 it was observed that particles of the final bottled material were indeed generally below $100 \mu \mathrm{m}$ (Supplementary Information, Fig. 2).

\subsection{Preliminary analysis of CRM-FDMT1}

To give a preliminary overview of the CRM toxin profile, concentrations of the regulated analogues relative to the EU regulatory levels are shown (Fig. 5). It can be seen that CRM-FDMT1 has a comprehensive toxin profile, with some analytes present at concentrations above and some below the regulatory level. These values are only considered indicative as the extraction procedures had not been fully optimised for complete recovery of the different toxins, no assessment of matrix effects was made for the LC-MS analysis, and calibrant CRMs were not available at this stage for each toxin analog present. In addition to the toxins represented in Fig. 5, the candidate CRM contains a variety of other analogs and isomers from the toxin groups present.

\section{Conclusions}

A candidate CRM for multiple groups of shellfish toxins has been prepared. Extensive effort was put into arrangement of the project, collection, collation, processing, purification and characterisation of the individual toxin materials, preparation of a bulk wet homogenate, and ultimately freeze-drying, processing and bottling of the candidate CRM. Almost 7000 units were produced, each containing approximately $3 \mathrm{~g}$ of freeze-dried powder. In regulatory analysis of shellfish toxins, freeze-dried matrices are not typically analysed, however, they are less susceptible to degradation and are therefore more efficient for ensuring the longterm stability required of a CRM. The CRMs representativeness of 'real-life' samples concedes to the various processes and treatments that are carried out during preparation of the material to ensure that it is fit for purpose (homogeneous and stable) over the necessary periods of time. However, the difference in the CRM-FDMT1 matrix should not present a major problem to analysts as it is accepted that natural samples routinely vary in composition and the analytical methods used must be robust enough to deal with these variations. 
Analytical process control of the bottled freeze-dried product showed that water content, particle size, and particle size distribution, were all appropriate. The candidate CRM contains the various toxins at a range of concentrations, which represents varying challenges for characterizing the homogeneity and stability of the material, as well as the ultimate certification exercise. It is important to note that toxin concentrations shown are only indicative values. The next phase of work is the full characterisation of CRM-FDMT1 at NRCIMB and development of methods to assign accurate certified values for the various toxins present in the final material.

\section{Acknowledgements}

This study was supported by the ASTOX project (funded by the The Marine Institute and National Development Plan (NDP) (ST/02/02, 2003 - 2006)), by the BIOTOX project (partly funded by the European Commission, through 6th Framework Programme contract no. 514074, priority Food Quality and Safety), by the Norwegian Research Council grant 139593/140, by the New Zealand Foundation for Research, Science and Technology (FRST), by the International Investment Opportunities Fund (IIOF contract number C10X0406), and by a FRST Post-Doctoral Fellowship (contract number AGRX0402). The routine shellfish toxin monitoring program in Ireland is funded by the Irish government.

The staff of the processing sector at IRMM, Jean Charoud-Got, Andrea Bau, Marie-France Tumba-Tshiliumba, Paul De Vos and Albert Oostra are gratefully acknowledged for their technical support as well as Hendrik Emons (also at IRMM) for facilitating and supporting this collaboration. The help of the Biotoxin Chemistry team at the Marine Institute is appreciated. We thank Morten Sandvik of the Norwegian Veterinary Institute and Allan D. Hawkes for assistance with supply of PTX2 and YTX.

The authors thank to Dr. Jeremy Melanson for reviewing this manuscript. This is NRCC publication number 51794 .

\section{References}

1. Wright JLC, Boyd RK, De Freitas ASW, Falk M, Foxall RA, Jamieson WD, Laycock MV, McCulloch AW, McInnes AG, Odense P, Pathak VP, Quilliam MA, Ragan MA, Sim PG, Thibault P, Walter JA, Gilgan M, Richard DJA, Dewar D (1989) Identification of domoic acid, a neuroexcitatory amino acid, in toxic mussels from eastern Prince Edward Island. Can $\mathrm{J}$ Chem 67:481-490

2. Yasumoto $T$, Murata M, Lee JA, Torigoe K (1978) Occurence of a new type of toxic shellfish poisoning in the Tohoku district. Bull Jpn Soc Sci Fish 44:1249-1255

3. Satake M, Ofuji K, Naoki H, James K, Furey A, McMahon T, Silke J (1998) Azaspiracid, a new marine toxin having unique spiro ring assemblies, isolated from Irish mussels, Mytilus edulis. J Am Chem Soc 120:9967-9968

4. CRL-MB CRLfMB (April 2007) Harmonised SOP for the Detection of Okadaic Acid, Dinophysistoxins and Pectenotoxins by Mouse Bioassay. Version 4 Vigo, Spain 2007 
5. Hess P, Grune B, Anderson DB, Aune T, Botana LM, Caricato P, van Egmond HP, Halder M, Hall S, Lawrence JF, Moffat C, Poletti R, Richmond J, Rossini GP, Seamer C, Serratosa Vilageliu J (2006) Three Rs Approaches in Marine Biotoxin Testing - The Report and Recommendations of a joint ECVAM/DG SANCO Workshop (ECVAM Workshop 55). Altern Labor Anim (ATLA) 34:193-224

6. Lee SO, Yanagi T, Kenma R, Yasumoto T (1987) Fluorometric determination of Diarrhetic Shellfish Toxins by High-Performance Liquid Chromatography. Agric Biol Chem 51 (3):877881

7. Quilliam MA, Sim PG, McCulloch AW, Mclnnes AG (1989) High performance liquid chromatography of domoic acid, a marine neurotoxin, with application to shellfish and plankton. Int J Environ Anal Chem 36:139-154

8. Suzuki T, Mitsuya T, Matsubara H, Yamasaki M (1998) Determination of pectentoxin-2 after solid phase extraction from seawater and from the dinoflagellate Dinophysis fortii by liquid chromatography with electrospray mass spectrometry and ultraviolet detection. Evidence of oxidation of pectenotoxin-2 to pectenotoxin-6 in scallops. J Chromatogr A 815:155-160

9. Ofuji K, Satake M, Oshima Y, McMahon T, James KJ, Yasumoto T (1999) A sensitive and specific determination method for azaspiracids by liquid chromatography mass spectrometry. Nat Toxins 7 (6):247-250.

10. Suzuki T, Horie Y, Koike K, Satake M, Oshima Y, Iwataki M, Yoshimatsu S (2007) Yessotoxin analogues in several strains of Protoceratium reticulatum in Japan determined by liquid chromatography-hybrid triple quadrupole/linear ion trap mass spectrometry. Journal of Chromatography A 1142 (2):172-177

11. Quilliam MA, Hess P, Dell'Aversano C (2001) Recent developments in the analysis of phycotoxins by liquid chromatography - mass spectrometry. De Koe WJ, Samson RA, van Egmond HP, Gilbert J, Sabino M (Eds) Proceedings of the Xth International IUPAC Symposium on Mycotoxins and Phycotoxins 21-25 May, 2000 Guaruja (Brazil):383-391

12. Stobo LA, Lacaze JP, Scott AC, Gallacher S, Smith EA, Quilliam MA (2005) Liquid chromatography with mass spectrometry--detection of lipophilic shellfish toxins. J AOAC Int 88 (5):1371-1382

13. Fux E, McMillan D, Bire R, Hess $P$ (2007) Development of an ultra-performance liquid chromatography-mass spectrometry method for the detection of lipophilic marine toxins. Journal of Chromatography A 1157 (1-2):273-280

14. McNabb P, Selwood AI, Holland PT, Aasen J, Aune T, Eaglesham G, Hess P, Igarishi M, Quilliam M, Slattery D, Van de Riet J, Van Egmond H, Van den Top H, Yasumoto T (2005) Multiresidue method for determination of algal toxins in shellfish: single-laboratory validation and interlaboratory study. J AOAC Int 88 (3):761-772

15. ISO-guide-30 (1992) Terms and definitions used in connection with reference materials. Geneva, Switzerland, ISO/IEC 
16. Emons H, Fajgelj A, Veen AMH, Watters $R$ (2006) New definitions on reference materials. Accreditation and Quality Assurance 10 (10):576-578

17. Emons $\mathrm{H}$ (2006) The 'RM family'-Identification of all of its members. Accreditation and Quality Assurance 10 (12):690-691

18. Hess P, McCarron P, Quilliam MA (2006) Fit-for-purpose shellfish reference materials for internal and external quality control in the analysis of phycotoxins. Analytical and Bioanalytical Chemistry 387 (7):2463-2474

19. Boenke A (1998) Activities and current research of the European Community standards, measurements and testing programme (SMT) in the area of phycotoxins. In: Harmful Algae, Reguera B, Blanco J, Fernández ML, Wyatt T (eds) Xunta De Galicia and Intergovernmental Oceanographic Commission (IOC) of UNESCO, Proceedings of the VIII International Conference on Harmful Algae, Vigo, Spain, 25-29 June 1997:211-215

20. Goto H, Igarashi T, Sekiguchi K, Tanno K, Satake M, Oshima Y, Yasumoto T (1998) A Japanese project for the production and distribution of shellfish toxins as calibrants for HPLC analysis. In: Harmful Algae, Reguera B, Blanco J, Fernández ML, Wyatt T (Eds) Xunta De Galicia and Intergovernmental Oceanographic Commission (IOC) of UNESCO, Proceedings of the VIII International Conference on Harmful Algae, Vigo, Spain, 25-29 June 1997:216219

21. van den Top HJ, Boenke A, Burdaspal PA, Bustos J, van Egmond HP, Legarda T, Mesego A, Mourino A, Paulsch WE, Salgado C (2001) The development of reference materials for paralytic shellfish poisoning toxins in lyophilized mussel. II: Certification study. Food Addit Contam 18 (9):810-824

22. Quilliam MA, Wright JLC (1989) The amnesic shellfish poisoning mystery. Analytical Chemistry 61 (18):1053-1060

23. Hardstaff WR, Jamieson WD, Milley JE, Quilliam MA, Sim PG (1990) Reference materials for domoic acid, a marine neurotoxin. Fresenius J Anal Chem 338:520-525

24. CRMP Website: http://www.nrc-cnrc.gc.ca/eng/programs/imb/crmp.html. Accessed: November $22^{\text {nd }}, 2010$

25. McCarron $P$, Hess $P$ (2006) Tissue distribution and effects of heat treatments on the content of domoic acid in blue mussels, Mytilus edulis. Toxicon 47 (4):473-479

26. McCarron P, Kilcoyne J, Hess P (2008) Effects of cooking and heat treatment on concentration and tissue distribution of okadaic acid and dinophysistoxin-2 in mussels (Mytilus edulis). Toxicon 51 (6):1081-1089

27. NRC-CNRC (2005) NRC CRM ASP-Mus-C: Mussel tissue reference material for domoic acid. Certificate of Analysis, National Research Council, Institute for Marine Bioscience.

28. NRC-CNRC (2005) NRC CRM-DSP-Mus-b: Mussel tissue reference material for DSP toxins. Certificate of Analysis, National Research Council, Institute for Marine Bioscience. 
29. Quilliam MA, Reeves K, MacKinnon S, Craft C, Whyte H, Walter J, Stobo L, Gallacher S (2006) Preparation of reference materials for azaspiracids. In: Deegan B, Butler C, Cusack C, Henshilwood K, Hess P, Keaveney S, McMahon T, O'Cinneide M, Lyons D, Silke J (eds) 5th International Conference of Molluscan Shellfish Safety, 14-18 June 2004, Galway, Ireland. The Marine Institute, 111-115, ISBN: 1 902895-33-9

30. McCarron P, Kotterman M, Boer J, Rehmann N, Hess P (2007) Feasibility of gamma irradiation as a stabilisation technique in the preparation of tissue reference materials for a range of shellfish toxins. Analytical and Bioanalytical Chemistry 387 (7):2487-2493

31. McCarron P, Burrell S, Hess P (2006) Effect of addition of antibiotics and an antioxidant on the stability of tissue reference materials for domoic acid, the amnesic shellfish poison. Analytical and Bioanalytical Chemistry 387 (7):2495-2502

32. Linsinger TPJ, Pauwels J, Van der Veen AMH, Schimmel H, Lamberty A (2001) Homogeneity and stability of reference materials. Accred Qual Assur 6:20-25

33. McCarron $P$, Emteborg $H$, Hess $P$ (2007) Freeze-drying for the stabilisation of shellfish toxins in mussel tissue (Mytilus edulis) reference materials. Analytical and Bioanalytical Chemistry 387 (7):2475-2486

34. Hess P, McCarron P, Rehmann N, Kilcoyne J, McMahon T, Ryan G, Ryan MP, Twiner M, Doucette G, Satake M, Ito E, Yasumoto T (2007) Isolation and purification of AZAs from naturally contaminated material, and evaluation of their toxicological effects (ASTOX). Marine Environment \& Health Series.

35. McCarron P, Kilcoyne J, Miles CO, Hess P (2009) Formation of Azaspiracids-3, -4, -6, and -9 via Decarboxylation of Carboxyazaspiracid Metabolites from Shellfish. J Agr Food Chem 57 (1):160-169

36. Loader JI, Hawkes AD, Beuzenberg V, Jensen DJ, Cooney JM, Wilkins AL, Fitzgerald $\mathrm{JM}$, Briggs LR, Miles CO (2007) Convenient large-scale purification of yessotoxin from Protoceratium reticulatum culture and isolation of novel furanoyessotoxin. J Agric Food Chem 55:11093-11100

37. Cembella A, Lewis N, Quilliam MA (2000) The marine dinoflagellate Alexandrium ostenfeldii (Dinophyceae) as the causative organism of spirolides shellfish toxins. Phycologia 39 (1):67-74

38. Rundberget T, Sandvik M, Larsen K, Pizarro G, Reguera B, Castberg T, Gustad E, Loader J, Rise F, Wilkins A (2007) Extraction of microalgal toxins by large-scale pumping of seawater in Spain and Norway, and isolation of okadaic acid and dinophysistoxin-2. Toxicon 50 (7):960-970

39. Quilliam MA, Xie M, Hardstaff W (1995) A Rapid Extraction and Cleanup Procedure for the Liquid Chromatographic Determination of Domoic Acid in Unsalted Seafood. J AOAC Int 78:543-554

40. Hess P, Kilcoyne J, Swords D, Mulcahy N, McCarron M, Keogh M, Gibbons B, Ronan J (2006) Impact of HPLC-UV methods (solid-phase extraction/UV detection and photodiodearray detection) for the determination of domoic acid on quality of results and sample 
turnaround time. In: Deegan B, Butler C, Cusack C, Henshilwood K, Hess P, Keaveney S, McMahon T, O'Cinneide M, Lyons D, Silke J (eds) 5th International Conference of Molluscan Shellfish Safety, 14-18 June 2004, Galway, Ireland. The Marine Institute, 77-80, ISBN: 1 902895-33-9

41. Mountfort DO, Suzuki T, Truman P (2001) Protein phosphatase inhibition adapted for determination of total DSP in contaminated mussel. Toxicon 39:383-390

42. Kestens V, Charoudgot J, Bau A, Bernreuther A, Emteborg H (2008) Online measurement of water content in candidate reference materials by acousto-optical tuneable filter near-infrared spectrometry (AOTF-NIR) using pork meat calibrants controlled by Karl Fischer titration. Food Chem 106 (4):1359-1365

43. Anonymous (2004) Regulation (EC) No 853/2004 of the European parliament and of the council of 29 April 2004 laying down specific hygiene rules for food of animal origin. Official Journal of the European Union L 139 of 30 April 2004

44. Carmody EP, James KJ, Kelly SS (1996) Dinophysistoxin-2: the predominant diarrhoetic shellfish toxin in Ireland. Toxicon 34 (3):351-359

45. Quevauviller P, Maier EA (1999) Interlaboratory studies and certified reference materials for environmental analysis: the BCR approach. In: Techniques and Instrumentation in Analytical Chemistry, Elsevier Science B.V. p 119, ISBN: 0-444-82389-1 
Tables

\begin{tabular}{|c|c|c|c|c|c|c|c|c|c|c|c|c|}
\hline Material & $\begin{array}{c}\text { replicate } \\
\text { samples } \\
\text { (n) }\end{array}$ & $\begin{array}{c}\text { DA \& } \\
\text { epiDA }\end{array}$ & $O A$ & $\begin{array}{c}\text { OA } \\
\text { esters }\end{array}$ & DTX1 & $\begin{array}{l}\text { DTX1 } \\
\text { esters }\end{array}$ & DTX2 & $\begin{array}{c}\text { DTX2 } \\
\text { esters }\end{array}$ & AZA1 & AZA2 & AZA3 & $\begin{array}{c}\% \\
\text { moisture } \\
\text { content } \\
(\mathrm{m} / \mathrm{m}) \\
\end{array}$ \\
\hline A & 3 & $\begin{array}{c}587 \\
(9)\end{array}$ & $n d$ & $n d$ & $n d$ & nd & nd & $n d$ & $n d$ & $n d$ & nd & $\begin{array}{l}79.6 \\
(0.5)\end{array}$ \\
\hline B & 5 & & $\begin{array}{c}0.04 \\
(0.01)\end{array}$ & $\begin{array}{c}0.10 \\
(0.03)\end{array}$ & $\begin{array}{c}0.4 \\
(0.1)\end{array}$ & $\begin{array}{c}0.4 \\
(0.1)\end{array}$ & $\begin{array}{c}0.07 \\
(0.01)\end{array}$ & $\begin{array}{c}0.05 \\
(0.03)\end{array}$ & $n d$ & $n d$ & $n d$ & $\begin{array}{l}77.6 \\
(0.1)\end{array}$ \\
\hline C & 8 & & $\begin{array}{c}0.10 \\
(0.03)\end{array}$ & $\begin{array}{c}0.09 \\
(0.03)\end{array}$ & nd & nd & $\begin{array}{c}0.8 \\
(0.1)\end{array}$ & $\begin{array}{c}0.2 \\
(0.1)\end{array}$ & $\begin{array}{c}0.22 \\
(0.01)\end{array}$ & $\begin{array}{c}0.05 \\
(0.01)\end{array}$ & $\begin{array}{c}0.06 \\
(0.01)\end{array}$ & $\begin{array}{c}82 \\
(0.2)\end{array}$ \\
\hline D & 5 & & $\begin{array}{c}0.19 \\
(0.02)\end{array}$ & $n d$ & nd & nd & $\begin{array}{c}0.050 \\
(0.001)\end{array}$ & $n d$ & $\begin{array}{c}6.4 \\
(1.1)\end{array}$ & $\begin{array}{c}1.8 \\
(0.4)\end{array}$ & $\begin{array}{c}1.2 \\
(0.2)\end{array}$ & $\begin{array}{l}81.3 \\
(0.4)\end{array}$ \\
\hline$E$ & 10 & & $\begin{array}{c}0.22 \\
(0.04)\end{array}$ & $\begin{array}{c}0.7 \\
(0.1)\end{array}$ & nd & nd & $\begin{array}{c}0.8 \\
(0.1)\end{array}$ & $\begin{array}{c}0.7 \\
(0.2)\end{array}$ & $n d$ & nd & nd & $\begin{array}{l}80.7 \\
(0.5)\end{array}$ \\
\hline
\end{tabular}

Table 1. Toxin concentrations in $\mathrm{mg} / \mathrm{kg}$ and moisture contents (standard deviations in parentheses) of the individual tissue materials collected for preparation of the multi-toxin CRM ( $n d=$ not detected). 


\begin{tabular}{|c|c|c|c|c|c|c|c|c|c|c|c|c|c|c|c|}
\hline Material & $\begin{array}{c}\text { Quantity } \\
\text { used } \\
\text { (kg) }\end{array}$ & Ratio & DA & OA & $\begin{array}{c}\text { OA } \\
\text { esters }\end{array}$ & DTX1 & $\begin{array}{l}\text { DTX1 } \\
\text { esters }\end{array}$ & DTX2 & $\begin{array}{l}\text { DTX2 } \\
\text { esters }\end{array}$ & AZA1 & $\mathrm{AZA} 2$ & AZA3 & YTX & PTX2 & $\begin{array}{c}\text { 13- } \\
\text { desMe- } \\
\text { SPX-C }\end{array}$ \\
\hline$A$ & 5.5 & 0.04 & 21.51 & & & & & & & & & & & & \\
\hline B & 11.3 & 0.08 & & 0.003 & 0.01 & 0.03 & 0.03 & 0.01 & 0.004 & & & & & & \\
\hline C & 29.1 & 0.19 & & 0.02 & 0.02 & & & 0.15 & 0.04 & 0.04 & 0.01 & 0.01 & & & \\
\hline $\mathrm{D}$ & 20.0 & 0.13 & & 0.03 & & & & 0.01 & & 0.85 & 0.24 & 0.16 & & & \\
\hline E & 52.1 & 0.35 & & 0.08 & 0.24 & & & 0.28 & 0.24 & & & & & & \\
\hline $\begin{array}{c}\text { Water } \\
\text { adjustment* }\end{array}$ & 32.2 & 0.21 & & & & & & & & & & & & & \\
\hline \multicolumn{3}{|c|}{ Purified YTX } & & & & & & & & & & & 58.0 & & \\
\hline \multicolumn{3}{|c|}{ Dinophysis spp. extract } & & 2.6 & & 10.9 & & & & & & & & 15.0 & \\
\hline \multicolumn{3}{|c|}{ A. ostenfeldii pellet } & & & & & & & & & & & & & 50.0 \\
\hline \multicolumn{3}{|c|}{$\begin{array}{c}\text { Projected wet tissue } \\
\text { concentrations (mg/kg) }\end{array}$} & 21.5 & 0.14 & 0.27 & 0.10 & 0.03 & 0.44 & 0.29 & 0.89 & 0.25 & 0.18 & 0.39 & 0.10 & 0.33 \\
\hline
\end{tabular}

* moisture content of combined tissues (80.8\%) was adjusted to ca. $85 \%$ for a combined

total of $150 \mathrm{~kg}$ of homogenate.

Table 2. Quantities of separate tissues that were used in combined homogenate, total toxin contribution of individual tissue materials $(\mathrm{mg} / \mathrm{kg})$ (derived from values in Table 1$)$, toxin quantities in non-tissue materials $(\mathrm{mg})$, and projected wet tissue concentrations in combined homogenate following moisture content adjustment. 


\begin{tabular}{|c|c|c|c|}
\hline Upper band limit & $\begin{array}{c}\text { Average particle size } \boldsymbol{I} \\
\boldsymbol{\mu m}, \mathbf{(} \mathbf{=} \mathbf{1 2})\end{array}$ & $\begin{array}{c}\text { Standard } \\
\text { deviation } / \boldsymbol{\mu m}\end{array}$ & $\begin{array}{c}\text { Relative standard } \\
\text { deviation } / \boldsymbol{\%}\end{array}$ \\
\hline $\mathrm{X}_{10}$ & 12.9 & 1.4 & 11 \\
\hline $\mathrm{X}_{16}$ & 17.7 & 1.4 & 7.8 \\
\hline $\mathrm{X}_{50}$ & 43.7 & 1.4 & 3.2 \\
\hline $\mathrm{X}_{84}$ & 94.4 & 3.0 & 3.2 \\
\hline $\mathrm{X}_{90}$ & 117.1 & 4.9 & 4.2 \\
\hline
\end{tabular}

Table 3. Average particle size, absolute and relative standard deviations for the predefined cumulative distributions $\mathrm{X}_{0}$ (upper band limit) for $\mathrm{n}=12$ of CRM-FDMT1. 

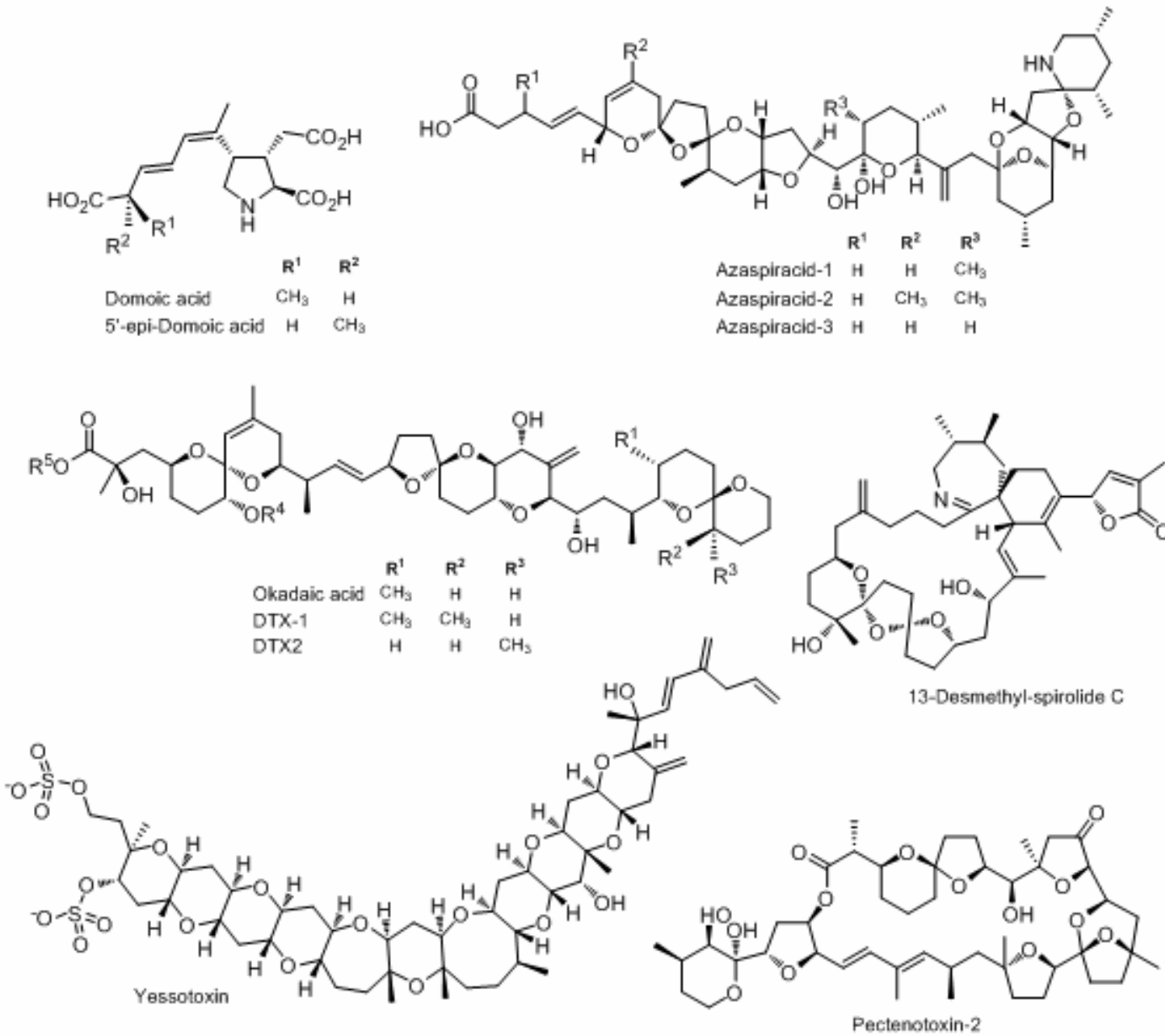

Figure 1: Structures of toxins representing the six different groups present in FDMT1. For the OA group of toxins a range of 7-O-acyl fatty acid esters, collectively called 'DTX3', are formed as metabolites in shellfish (attach at $\mathrm{R}^{4}$ ). In phytoplankton another group of $\mathrm{OA}$ derivatives called 'OA diol-esters' are formed by conjugation of the carboxyl group $\left(R^{5}\right)$. 


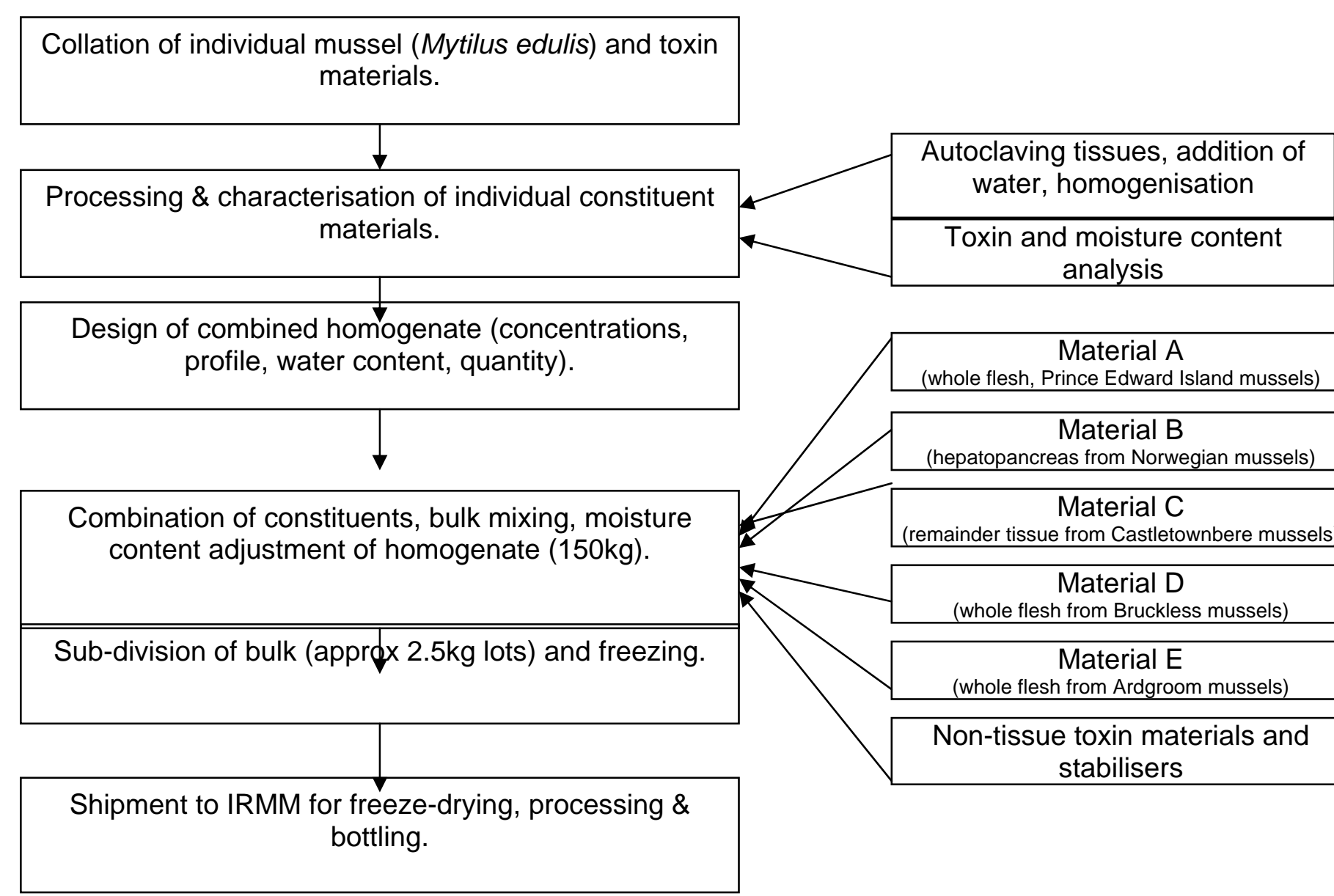

Figure 2: Schematic overview for preparation of bulk wet tissue homogenate at the MI. 


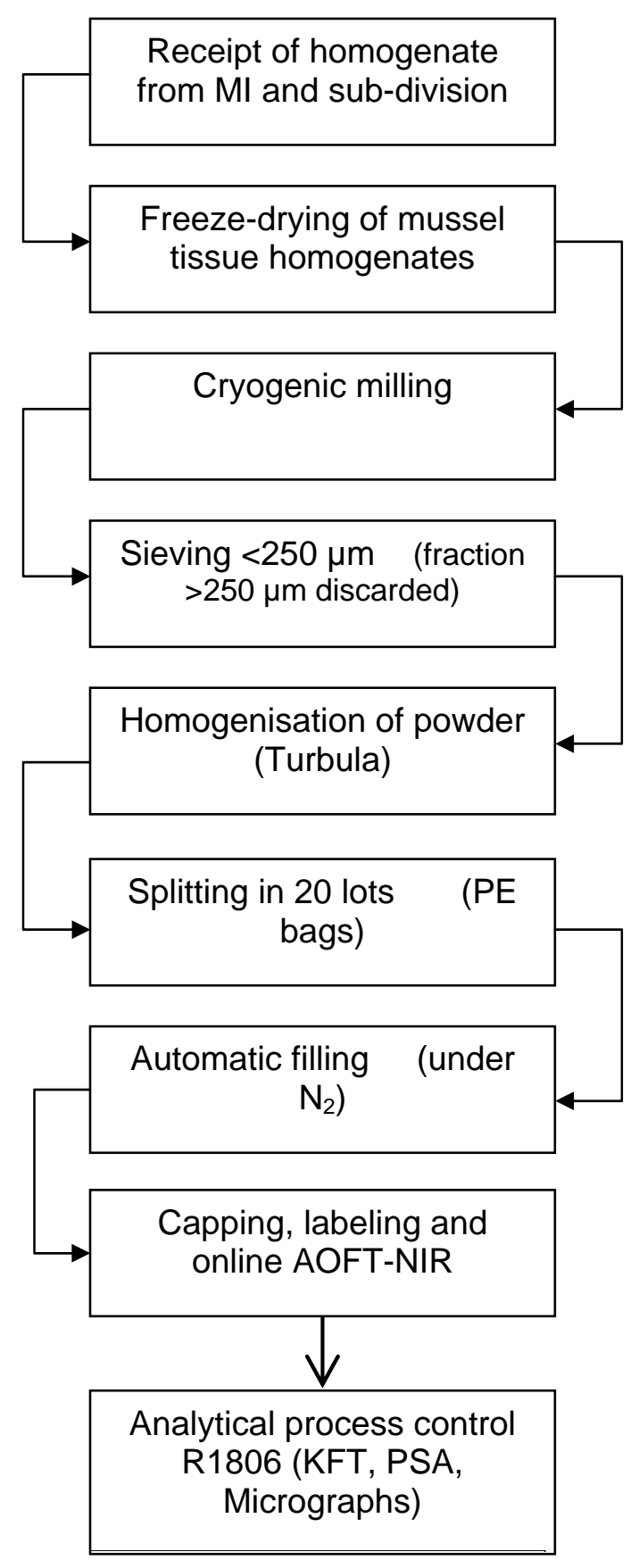

Figure 3: Schematic overview of process for transformation of wet mussel homogenate into CRM-FDMT1 at the IRMM. 


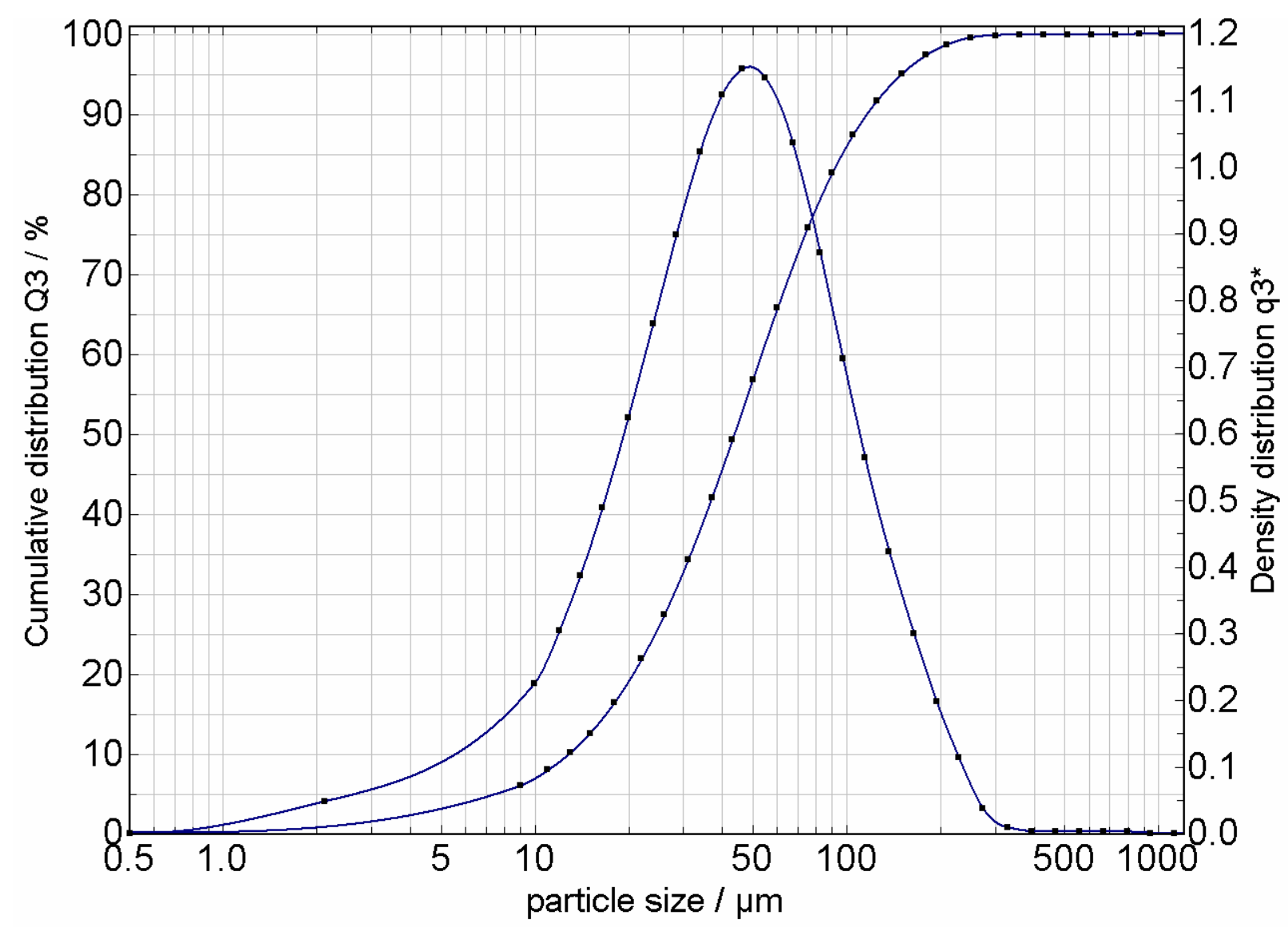

Figure 4: Average particle size distribution for twelve different samples of mussel powder as given in Table 3. Average optical concentration was $18.6 \%$. 


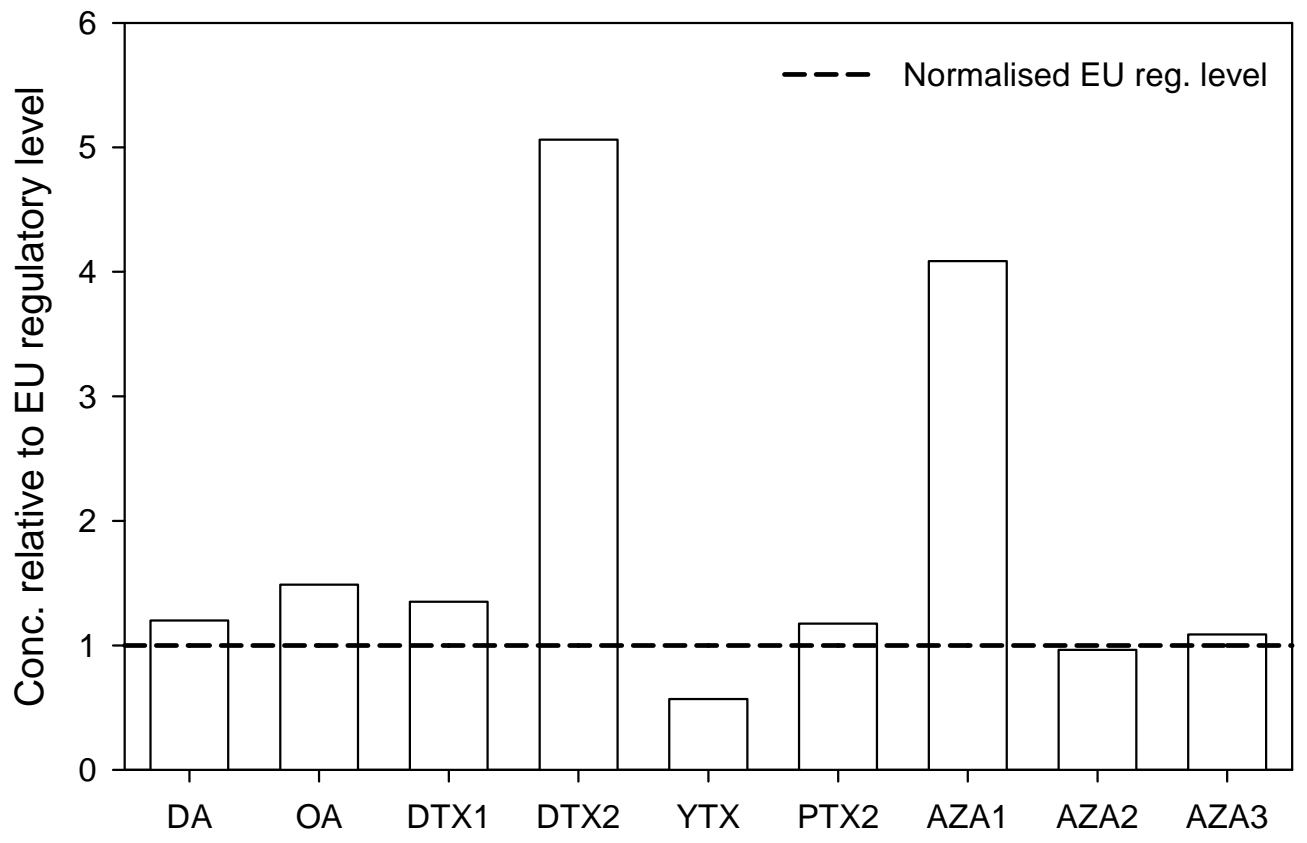

Figure 5: Projected concentrations of regulated analogs present in CRM-FDMT1 expressed relative to EU regulatory levels (represented by red line). The values are represented as re-constituted wet weight tissue concentrations of CRM-FDMT1. 